Perspective for Cellular Microbiology Special Issue in honour of Pascale Cossart

\title{
When bacteria meet mitochondria: the strange case of the tick symbiont Midichloria mitochondrii
}

Fabrizia Stavru ${ }^{1,2, \#,}$, Jan Riemer ${ }^{3}$, Aaron Jex $^{5,6}$, Davide Sassera $^{7}$

\begin{abstract}
1 Unité de Biologie Evolutive de la Cellule Microbienne, Institut Pasteur, Paris, France
2 CNRS ERL6002, Paris, France

3 Department for Chemistry, Institute for Biochemistry, University of Cologne, Cologne, Germany.

4 Population Health and Immunity Division, The Walter and Eliza Hall Institute of Medical Research, $1 G$ Royal Parade, Parkville, Victoria 3052, Australia

5 Department of Medical Biology, The University of Melbourne, Victoria 3010, Australia

6 Faculty of Veterinary and Agricultural Sciences, The University of Melbourne, Corner of Park and Flemington Road, Parkville, Victoria 3010, Australia

7 Department of Biology and Biotechnology, University of Pavia, via Ferrata 9, 27100, Pavia, Italy
\end{abstract}

\# corresponding author: fabrizia.stavru@pasteur.fr, tel +33-1-40613782

\section{Running title}

This is the author manuscript accepted for publication and has undergone full peer review but has not been through the copyediting, typesetting, pagination and proofreading process, which may lead to differences between this version and the Version of Record. Please cite this article as doi: $10.1111 / \mathrm{cmi} .13189$

This article is protected by copyright. All rights reserved. 
Perspective: mitochondrial colonization by Midichloria mitochondrii

\section{Keywords}

intracellular bacteria, symbiosis, mitochondria, Midichloria mitochondrii, Ixodes ricinus

This article is protected by copyright. All rights reserved. 


\begin{abstract}
Mitochondria are key eukaryotic organelles that perform several essential functions. Not surprisingly, many intracellular bacteria directly or indirectly target mitochondria, interfering with innate immunity, energy production or apoptosis, to make the host cell a more hospitable niche for bacterial replication. The alphaproteobacterium Midichloria mitochondrii has taken mitochondrial targeting to another level by physically colonizing mitochondria, as shown by transmission electron micrographs of bacteria residing in the mitochondrial intermembrane space. This unique localization provokes a number of questions around the mechanisms allowing and reasons driving intramitochondrial tropism. We suggest possible scenarios that could lead to this peculiar localization and hypothesize potential costs and benefits of mitochondrial colonization for the bacterium and its host.
\end{abstract}

This article is protected by copyright. All rights reserved. 


\section{Introduction}

Symbiosis, the tight interaction of organisms from different species, is ubiquitous in nature, across all branches of the tree of life (Brucker and Bordenstein, 2012). Intracellular symbioses are among the most fascinating, as they clearly require constant and complex interaction between the symbiont and its host (Wernegreen, 2012). All symbiotic relationships can have important impact on both partners, and intracellular symbioses can also play key roles in the evolution of hosts and symbionts (Archibald, 2015; Brucker and Bordenstein, 2012). The archetype of intracellular symbiosis is the evolution of mitochondria from a bacterial ancestor, an event that was instrumental for the evolution of eukaryotic cells and multicellularity (Gray et al., 2001; Roger et al., 2017).

Despite their prevalence and foundational role in shaping eukaryotic evolution, our knowledge of intracellular symbiosis between bacteria and eukaryotic cells remains sparse. Recent studies have started to unveil the molecular basis of some specific cases of symbiotic bacteria-cell interactions (e.g (Douglas, 2014)), but advances are limited by the paucity of genetically amenable systems and culturable symbionts. Arthropods are among the most studied symbiotic hosts, due to their extreme species-richness, broad distribution and importance as pathogen vectors, but also due to their strong propensity to harbour symbionts (Gil and Latorre, 2019). Many intracellular mutualists of arthropods play fundamental nutritional roles, supplementing the diets of hosts that feed on unbalanced substrates such as phloem sap or blood (Moran et al., 2008). Ticks are obligate hematophagous arthropods and appear to be a true "receptacle" for a wide variety of both pathogenic and non-pathogenic bacteria (Duron et al., 2017; Kernif et al., 2016). A portion of these tick-borne bacteria are maternally inherited, obligate intracellular bacteria and are thought to be nutritional symbionts (Bonnet et al., 2017). Here, we will focus on Candidatus Midichloria mitochondrii (hereafter $M$. mitochondrii), a maternally inherited symbiont that can colonize the oocyte mitochondria of the tick Ixodes ricinus, one of the most widespread ticks in Europe.

\section{Mitochondria, an emerging target for intracellular bacteria}

Mitochondria originated when an ancestral proteobacterium entered the ancestor of eukaryotic cells, a unique and crucial event for the evolution of eukaryotic life. Determining the nature of the bacterial lineage giving rise to the ancestor of mitochondria is a highly debated topic, and among other hypotheses (Martijn et al., 2018), one points at intracellular alphaproteobacteria of the Rickettsiales order as possible candidates for the closest extant relatives of the organelle, based on phylogenetic analyses (Andersson et al., 1998; Ferla et al., 2013; Fitzpatrick et al., 2006; Sassera et al., 2011; Wang and Wu, 2015; Williams et al., 2007). Mitochondria are essential eukaryotic organelles responsible for vital functions including energy production; biogenesis of iron-sulphur clusters, porphyrin and lipids;

This article is protected by copyright. All rights reserved. 
anaplerotic reactions; amino acid metabolism and programmed cell death (intrinsic apoptosis (Green et al., 2014)).

Most of our knowledge on mitochondria stems from model organisms, essentially yeast or mammalian cells, and most key mitochondrial functions and molecular machineries appear largely conserved (Pernas and Scorrano, 2016; Westermann, 2010). Due to their central role as metabolic and signalling hubs, mitochondria are a prime target for intracellular bacteria, which can obtain nutrients from them or manipulate intrinsic apoptosis. Indeed, several intracellular bacteria, associated with a range of eukaryotic hosts, can affect mitochondria (reviewed in (Spier et al., 2019)). The bacterial effects on mitochondria include morphological and functional changes, as exemplified by the facultative intracellular bacterium Listeria monocytogenes, which induces fragmentation of the mitochondrial network while leading to a collapse of the mitochondrial membrane potential (Stavru et al., 2011). Several bacteria target mitochondria through secreted proteins that act directly on the organelles. For example, Helicobacter pylori secretes the toxin VacA, which is inserted in the mitochondrial inner membrane (Foo et al., 2010), while the Listeria toxin listeriolysin $O$ inserts into the plasma membrane, causing a calcium influx and thus indirectly leading to mitochondrial fission (Stavru et al., 2011). Some bacteria even interact physically with mitochondria, establishing close contacts. Stable contacts have been detected between mitochondria and the avian pathogen Chlamydia psittaci, increasing concomitantly to bacterial replication. This led the authors to suggest that mitochondria might provide ATP for bacterial replication via the $C$. psittaci - encoded ATP-ADP transporter (Matsumoto et al., 1991). In contrast, the human pathogen Legionella pneumophila was shown to establish dynamic contacts with mitochondria that were lost at late timepoints of infection. In addition, these contacts were also observed upon infection with avirulent $L$. pneumophila (deficient in the type four secretion system), leading the authors to propose that transient mitochondrial association with bacteria-containing phagosomes might represent a general, virulence-independent host response to infection (Escoll et al al.__2017). The recently described alphaproteobacterium Midichloria mitochondrii (Sassera et al., 2006) provides one of the most extreme examples of a physical interaction between an intracellular bacterium and mitochondria.

\section{Midichloria mitochondrii}

Midichloria is a genus of obligate intracellular bacteria belonging to the order Rickettsiales, a group of alphaproteobacteria composed by intracellular bacteria (with one exception (Castelli et al., 2019)), which includes human pathogens (e.g many Rickettsia species (Parola et al., 2013; Weinert et al., 2009)), mutualists (Hosokawa et al., 2010; Landmann, 2019; Taylor et al., 2005), reproductive parasites (Werren et al., 2008), and a number of lessstudied lineages with unknown interactions with their host (Castelli et al., 2016). Midichloriae have been found in several tick species, including Ixodes ricinus (Beninati et al.,

This article is protected by copyright. All rights reserved. 
2004), Rhipicephalus bursa (Epis et al., 2008), Amblyomma maculatum (Budachetri et al., 2018), among others (Cafiso et al., 2016; Epis et al., 2008). These bacteria are among the most abundant members of the microbiome in multiple tick species (Di Lecce et al., 2018; Duron et al., 2017; Hernández-Jarguín et al., 2018), suggesting a potential mutualistic relationship (Lo et al., 2006) and mechanisms to avoid immune recognition by the host.

Among Midichloriae, the most studied is Candidatus Midichloria mitochondrii (hereafter M. mitochondrii). M. mitochondrii is present at high prevalence and abundance in females and immature I. ricinus ticks (Lo et al., 2006; Sassera et al., 2008). Ixodes ricinus is also a competent vector for a range of viral, parasitic and bacterial diseases of high medical impact (Lejal et al., 2019; Moutailler et al., 2016; Reis et al., 2011). Diseases transmitted by I. ricinus include the highly virulent tick-borne encephalitis caused by the homonymous virus, rickettsioses, and Lyme disease caused by multiple Borrelia species (Boulanger et al., 2019). Most characteristics of the host-symbiont relationship between I.ricinus and M.mitochondrii are those common to nutritional mutualisms: high prevalence, widespread distribution, transovarial transmission, low symbiont genetic diversity, and symbiont genome reduction while retaining B vitamin synthesis genes (Al-Khafaji et al., 2019; Lo et al., 2006; Sassera et al., 2011).

Although it is largely unknown whether $M$. mitochondrii plays a role in pathogen transmission, or is itself productively transmitted through blood feeding (Bazzocchi et al., 2013; Cafiso et al., 2019; Mariconti et al., 2012a; Serra et al., 2019), one study found a positive correlation between levels of the Midichloria symbiont of a different tick species (Amblyomma maculatum) and the presence of the pathogen Rickettsia parkeri (Budachetri et al., 2018). However, what makes the interaction between $M$. mitochondrii and its host unique is the astonishing observation that $M$. mitochondrii is not only present in the cytoplasm, but a portion of its population colonises the intermembrane space of mitochondria (Fig 1) and appears to lead to mitochondrial matrix condensation (Sacchi et al., 2004). Such peculiar localization, never reported in any other animal cell, raises major questions: (1) How and why does M. mitochondrii get into mitochondria and how do mitochondria respond? (2) What is the role of M.mitochondrii in the cell, and does this benefit the host? (3) Why does invasion of mitochondria not lead to cell death? In the following paragraphs, we will address these questions by summarizing the available data and putting forward hypotheses and experimental approaches to test them.

\section{Mitochondria as an unexpected ecological niche}

The origin and evolution of the intramitochondrial tropism (IMT) displayed by $M$. mitochondrii are currently unknown. Another Midichloria symbiont was reported to be capable of IMT, in R. bursa ticks (Epis et al., 2008). Although Midichloria are the only bacteria capable of intramitochondrial tropism in a metazoan organism described to date, other bacteria have been reported as intramitochondrial or very closely associated to

This article is protected by copyright. All rights reserved. 
mitochondria in protists. Examples for IMT/mitochondrial association are found in bacteria that colonize the protists Halteria geleiana (Yamataka and Hayashi, 1970), Urotricha ovata Kahl (de Puytorac and Grain, 1972) and more recently two Diplomonas species (Diplonema japonicum and Diplonema aggregatus), whose bacterial endosymbionts were the founding members of the new genus "Candidatus Cytomitobacter" (Tashyreva et al., 2018). The most parsimonious explanation to multiple phylogenetically unrelated bacteria invading or interacting very closely with mitochondria is the parallel independent evolution of these interactions, while a potential alternative would be an event of horizontal transfer of genes that mediate IMT. Future studies will uncover whether these bacteria employ common strategies to colonize mitochondria. In any case, the localization of bacteria in the mitochondrial intermembrane space (IMS) raises the question of the physiological reasons and advantages this localization might have. Here, we put forward hypotheses, focusing on the $M$. mitochondrii - I. ricinus system and drawn from our knowledge of mitochondrial IMS biology in model systems. In addition, our own unpublished transcriptome data of $M$. mitochondrii and/or I. ricinus also support to a certain degree the existence of signaling and metabolic pathways, as well as of homologs of the proteins that are mentioned in the following paragraphs.

The IMS as a protected space: avoiding cytosolic host defence mechanisms and modulating apoptosis

One possible explanation for the localization of $M$. mitochondrii in the IMS is that IMT can offer protection by escaping cytosolic defence machineries based on innate immune recognition or xenophagy. As, in contrast to other tissues, mitochondria are usually quite dormant in oocytes (Tiwari et al., 2015), they could represent a protected space without much reactive oxygen species production taking place. In addition, it potentially confers the ability to actively suppress dangerous pathways originating from mitochondria. For example, it might give the bacterium the capacity to modulate the host mitochondrion so as to avoid apoptosis induction (Tiwari et al., 2015), e.g by suppressing cytochrome c release and preventing cristae remodeling (Polčic et al., 2017). This could allow the suppression of mitophagy and $\mathrm{Ca}^{2+}$ signaling, which eventually might result in $\mathrm{Ca}^{2+}$ overload in mitochondria, followed by permeability transition and cell death (Orrenius et al., 2015). In addition, intramitochondrial $M$. mitochondrii might also modulate the immune response by preventing the release of mitochondrial DNA that is known to induce the innate immune response (Nakahira et al., 2011).

\section{The IMS: a microreactor?}

In addition to providing protection, the physical and chemical conditions of the IMS might constitute a favourable environment for $M$. mitochondrii. For example, the proximity to the mitochondrial respiratory chain might under certain conditions provide more suitable conditions for bacterial growth. For example, it has been reported in mammalian cells that inside mitochondria, close to the respiratory chain, the temperature can be significantly

This article is protected by copyright. All rights reserved. 
above that of the cytosol (Chrétien et al., 2018). Whether this temperature difference is also found in tick oocyte mitochondria remains an open question. While the overall GC content of the M.mitochondrii (37\%) does not seem to be specifically tailored for high temperatures, this needs to be confirmed by comparative analysis of its 16S rRNA GC content with that of non-mitochondrial Midichloriae (Wang et al., 2006). The IMS might also serve as a hub to exchange metabolites between host and bacterium. Indeed, ATP concentrations in the IMS are comparatively high and might be used directly by the bacterium. The existence of a putative ATP-ADP translocase in the bacterium can support this hypothesis, although $M$. mitochondrii appears to have retained the ability to synthesize ATP (Sassera et al., 2011). In contrast, several other obligate intracellular bacteria, which display highly reduced genomes, have lost the ability to synthesize nucleotides and therefore rely on ATP import from the host (energy parasitism, shown e.g. by Chlamydiae (Trentmann et al., 2007), Lawsonia intracellularis (Schmitz-Esser et al., 2008) and Rickettsia prowazekii (Winkler and Daugherty, 1984). In addition, the IMM and the IMS are important sites for cellular lipid metabolism, and the bacterium might benefit from direct lipid supply. Moreover, positioning in the IMS might allow the bacterium to influence AMP signaling (i.e. potentially to increase mitochondrial biogenesis), that is in part driven by the IMS-localized adenylate kinase 2 enzyme (Dzeja and Terzic, 2009).

The IMS as shuttle for transfer to the next generation

Transovarian transmission to the next generation is clearly the reason why many intracellular symbionts reside in female reproductive organs, however in the specific case of M. mitochondrii an additional factor contributing to its accumulation in oocytes could be the high number of mitochondria found in oocytes (up to 100 times more than in an epithelial cell (Monnot et al., 2013). A last hypothesis on the reason for the IMS localization is that mitochondria in general might serve as shuttles that allow $M$. mitochondrii to efficiently pass from one generation to the next, as the bacterium would then hijack the obligate maternal inheritance of mitochondria to ensure its own transmission. After fertilization, mitochondria initially do not have to divide but are distributed among cells of the early embryo. This might therefore also form a way for the bacterium to efficiently spread to multiple tissues in the next generation.

\section{Scenarios for mitochondrial colonization by M. mitochondrii}

Electron micrographs (EM) support inference of various possible scenarios for the life cycle of $M$. mitochondrii, and are complemented by similar work used to understand now wellcharacterized intracellular bacteria, including pathogens like Listeria monocytogenes (Tilney and Portnoy, 1989) or symbionts like Wolbachia, a member of the order Rickettsiales like $M$. mitochondrii (Avakyan and Popov, 1984). Wolbachia accumulate inside a host-derived vacuole (e.g. (Fischer et al., 2014)). It appears that cytosolic M. mitochondrii do not (see Fig. 1 and (Sacchi et al., 2004)). Although it is also possible that $M$. mitochondrii resides only

This article is protected by copyright. All rights reserved. 
temporarily in a vacuole, which might allow the bacterium to escape into the cytosol or fuse with the mitochondrial outer membrane, resulting in its observed IMS localization (Fig 2). Alternatively, cytosolic bacteria could directly enter mitochondria, possibly hijacking mitochondrial fusion. Unfortunately, EM precludes the analysis of dynamic events, and therefore validation of either model critically depends on the ability to perform functional tests, and therefore on the ability to manipulate $M$. mitochondrii in vitro, which is yet to be developed.

Once inside mitochondria, M. mitochondrii appears to manipulate the contacts that normally keep the inner and outer membrane at a constant distance of about $20 \mathrm{~nm}$, sometimes leading to substantial separation of the inner and outer membrane (Fig $1 \mathrm{C}$ and (Sacchi et al., 2004)). 3D analyses and quantitative light microscopy will be required to address whether $M$. mitochondrii modulates mitochondrial dynamics in addition to affecting mitochondrial ultrastructure. Such approaches will also be instrumental to determine the proportion of cytoplasmic versus mitochondrial M. mitochondrii. Strikingly, several examples of mitochondria colonized by more than one bacterium have been reported, suggesting either multiple rounds of invasion or bacterial division within the IMS. The presence of multiple bacteria appears correlated with altered mitochondrial ultrastructure up to drastic mitochondrial matrix condensation (Fig 1C and (Sacchi et al., 2004)) and it is reasonable to expect these alterations to affect mitochondrial function. Surprisingly, these mitochondrial changes do not correlate with an apparent induction of cell death. We hypothesize that the bacterium actively counters apoptosis, similar to other obligate intracellular bacteria (Rudel et al., 2010) .

While several tick species harbour bacteria belonging to the Midichloria genus, currently the only complete genome available for this genus is that of Midichloria mitochondrii, a putative symbiont of the hard tick $I$. ricinus. The reduced genome of $M$. mitochondrii (1.2Mb) is indeed typical of rickettsial endosymbionts (Sassera et al., 2011). Comparative genomics between $M$. mitochondrii and closely related species that do not display IMT (e.g. Midichloria from Ixodes holocyclus (Beninati et al., 2009; Castelli et al., 2016) will therefore be instrumental to uncover whether specific genes are associated with the unique ability of the symbiont to invade mitochondria. However, the $M$. mitochondrii genome already unveiled an intriguing and surprising finding: the presence of flagellar genes, including components of the motor and export apparatus (Sassera et al., 2011). Even though the flagellum of $M$. mitochondrii has never been visualized, hook and filament proteins have been detected experimentally (Mariconti et al., 2012b). A typical PAMP (pathogen associated molecular pattern), the flagellum can be recognized by Toll-like receptor family proteins, which are highly conserved in eukaryotes (reviewed in (Leulier and Lemaitre, 2008)). Consequently, flagellar genes have been lost or are not expressed in several intracellular bacteria or endosymbionts, including most members of the Rickettsiales (Toft and Fares, 2008). Given the immunogenicity and significant energetic cost associated with flagellar synthesis (Toft and Fares, 2008), it is likely that M. mitochondrii flagella play an

This article is protected by copyright. All rights reserved. 
important role in the bacterial life cycle. Such role may be difficult to imagine, if we only think about the motility function of this structure, but flagella have recently been shown to have also other functions, in particular bacterial adhesion and invasion (Haiko and Westerlund-Wikström, 2013) and symbiotic interactions (Shimoyama et al., 2009). Alternatively, the flagellum of $M$. mitochondrii might actually represent a type three secretion system that could mediate adhesion (e.g. to mitochondria) or contribute to host cell manipulation through the secretion of bacterial proteins, similar to other intracellular bacteria (Ashida et al., 2007; Mueller et al., 2014; Waterman and Holden, 2003; Zhang et al., 2012). The flagellum might thus be the key to the interaction between the symbiont and the organelle.

\section{Possible implications of mitochondrial colonization by M. mitochondrii}

Genomic information allows to formulate hypotheses concerning the impact of $M$. mitochondrii on its host physiology, which await experimental testing. Ecological studies detected high prevalence and low genetic variability of $M$. mitochondrii (Al-Khafaji et al., 2019; Lo et al., 2006), suggesting it could be beneficial to I.ricinus, however this is not proven and its specific impact on the host cell or host physiology are unclear, as are the mechanisms of interaction with mitochondria. A current hypothesis is that the bacterium improves host cellular respiration during blood feeding, during which ixodid ticks are thought to enter a hypoxic state. Indeed, the M. mitochondrii genome has been found to encode a complex IV cbb3 cytochrome oxidase that allows oxidative phosphorylation at low oxygen tension (Sassera et al., 2011). This intriguing finding, together with the presence of a bacterially encoded ATP transporter and an observed increase in the bacterial population in response to low oxygen tension and high metabolic needs in the host has led to propose that $M$. mitochondrii could assist the tick cellular respiration during this specific stage of its life cycle (i.e., feeding; (Sassera et al., 2008)). In addition, M. mitochondrii might also provide I. ricinus with metabolites or vitamins, as recently proven for another intracellular symbiont of the Francisella genus, which provides B vitamins to its host, the African soft tick Ornithodoros moubata (Duron et al., 2018). I. ricinus apparently lacks all enzymes for porphyrin (haem) biosynthesis except for the last three enzymes (Perner et al., 2016). Curiously, the first enzyme encoded in the I. ricinus genome is coproporphyrinogen III oxidase (CPOX). In higher eukaryotes, this enzyme is localized in the IMS and it is tempting to speculate that $M$. mitochondrii provides precursors for this enzyme. $M$. mitochondrii might also play a role in the regulation of mitochondrial reactive oxygen species (ROS) production. Functionally, ROS detoxification by antioxidants has been shown to play a role in maintaining fertility/fecundity in Drosophila (Parkes et al., 1998) and mosquitoes (DeJong et al., 2007), and maternally inherited arthropod symbionts such as Wolbachia have been shown to regulate ROS levels (Zug and Hammerstein, 2015). In ticks, an example of ROS manipulation

This article is protected by copyright. All rights reserved. 
by bacteria is given by the pathogen $A$. phagocytophilum, which has recently been shown to inhibit ROS production and apoptosis to preserve its replicative niche (Alberdi et al., 2019).

\section{Midichloria mitochondrii in non-ovarian tissues}

Recently M. mitochondrii has been detected in other tick organs, including salivary glands (Mariconti et al., 2012a), malpighian tubules, tracheae and guts (Olivieri et al., 2019). This finding led to hypothesize different functions for the bacterial populations residing in different organs. M. mitochondrii subpopulations could not just be supplying essential nutrients to the host but also enhance the reproductive fitness, helping in anti-oxidative defence, energy production, water balance and homeostasis. More 'selfish' reasons for the multiple localizations include ensuring both vertical transmission ( $M$. mitochondrii in oocytes) and horizontal transmission to the vertebrate host during the blood meal ( $M$. mitochondrii in salivary glands), as well as optimization of energy parasitism. While giving some answers, these findings also open a novel question: is $M$. mitochondrii localized also in mitochondria in tissues other than oocytes? The low bacterial load makes electron microscopy a frustrating endeavor, and correlative approaches will be required to definitively answer this question.

\section{Outlook}

Mitochondria are highly conserved across almost all eukaryotes and are intensively studied due to their role in aging, cancer and in a variety of pathologies (Nunnari and Suomalainen, 2012). Despite this, many aspects of mitochondrial biology are unknown and $30 \%$ of mitochondrial proteins have an unknown function. Studying the crosstalk between $M$. mitochondrii and mitochondria might provide novel insight into mitochondrial biology, much like the study of Listeria monocytogenes has yielded invaluable insight into fundamental cell biological processes of its eukaryotic host cells (Cossart, 2011).

\section{Acknowledgements}

The authors declare no conflict of interest.

This review is dedicated to Pascale Cossart, thanking her for her long-standing mentorship and support. We would like to thank Luciano Sacchi and Emanuela Clementi for providing the TEM images of figure 1, Claudio Bandi for planting the seed of this collaboration, Sarah Bonnet for critical reading of the manuscript and the Human Frontier Science Program for funding (Grant RGY0075/2017). AJ also acknowledges funding the Australian National Health and Medical Research Council (APP1126345) and infrastructure support funding through the

This article is protected by copyright. All rights reserved. 
Victorian state government. DS acknowledges the Italian Ministry of Education, University and Research (MIUR): Dipartimenti di Eccellenza Programme (2018-2022)-Department of Biology and Biotechnology "L. Spallanzani", University of Pavia. FS acknowledges the support of Institut Pasteur. We apologize to all colleagues whose work we could not cite for space reasons.

\section{Author contributions}

Primary draft: FS, with contribution by JR and DS. Figure 2 drafted by FS, layout and final preparation AJ. All authors edited the manuscript.

\section{List of Figure Legends}

Figure 1: Transmission electron micrograph of I.ricinus oocytes colonized by M. mitochondrii. Figure 2: Different scenarios for the life cycle of M.mitochondrii.

This article is protected by copyright. All rights reserved. 


\section{REFERENCES}

Alberdi, P., Cabezas-Cruz, A., Prados, P.E., Rayo, M.V., Artigas-Jerónimo, S., de la Fuente, J., 2019. The redox metabolic pathways function to limit Anaplasma phagocytophilum infection and multiplication while preserving fitness in tick vector cells. Sci Rep 9, 13236. https://doi.org/10.1038/s41598-019-49766-X

Al-Khafaji, A.M., Clegg, S.R., Pinder, A.C., Luu, L., Hansford, K.M., Seelig, F., Dinnis, R.E., Margos, G., Medlock, J.M., Feil, E.J., Darby, A.C., McGarry, J.W., Gilbert, L., Plantard, O., Sassera, D., Makepeace, B.L., 2019. Multi-locus sequence typing of Ixodes ricinus and its symbiont Candidatus Midichloria mitochondrii across Europe reveals evidence of local co-cladogenesis in Scotland. Ticks Tick Borne Dis 10, 52 62. https://doi.org/10.1016/j.ttbdis.2018.08.016

Andersson, S.G., Zomorodipour, A., Andersson, J.O., Sicheritz-Pontén, T., Alsmark, U.C., Podowski, R.M., Näslund, A.K., Eriksson, A.S., Winkler, H.H., Kurland, C.G., 1998. The genome sequence of Rickettsia prowazekii and the origin of mitochondria. Nature 396, 133-140. https://doi.org/10.1038/24094

Archibald, J.M., 2015. Endosymbiosis and Eukaryotic Cell Evolution. Curr. Biol. 25, R911921. https://doi.org/10.1016/j.cub.2015.07.055

Ashida, H., Toyotome, T., Nagai, T., Sasakawa, C., 2007. Shigella chromosomal IpaH proteins are secreted via the type III secretion system and act as effectors. Mol. Microbiol. 63, 680-693. https://doi.org/10.1111/j.1365-2958.2006.05547.x

Avakyan, A.A., Popov, V.L., 1984. Rickettsiaceae and Chlamydiaceae: comparative electron microscopic studies. Acta Virol. 28, 159-173.

Bazzocchi, C., Mariconti, M., Sassera, D., Rinaldi, L., Martin, E., Cringoli, G., Urbanelli, S., Genchi, C., Bandi, C., Epis, S., 2013. Molecular and serological evidence for the circulation of the tick symbiont Midichloria (Rickettsiales: Midichloriaceae) in different mammalian species. Parasit Vectors 6, 350. https://doi.org/10.1186/17563305-6-350

Beninati, T., Lo, N., Sacchi, L., Genchi, C., Noda, H., Bandi, C., 2004. A novel alphaProteobacterium resides in the mitochondria of ovarian cells of the tick Ixodes ricinus. Appl. Environ. Microbiol. 70, 2596-2602. https://doi.org/10.1128/aem.70.5.25962602.2004

Beninati, T., Riegler, M., Vilcins, I.-M.E., Sacchi, L., McFadyen, R., Krockenberger, M., Bandi, C., O’Neill, S.L., Lo, N., 2009. Absence of the symbiont Candidatus Midichloria mitochondrii in the mitochondria of the tick Ixodes holocyclus. FEMS Microbiol. Lett. 299, 241-247. https://doi.org/10.1111/j.1574-6968.2009.01757.x

Bonnet, S.I., Binetruy, F., Hernández-Jarguín, A.M., Duron, O., 2017. The Tick Microbiome: Why Non-pathogenic Microorganisms Matter in Tick Biology and Pathogen Transmission. Front Cell Infect Microbiol 7, 236. https://doi.org/10.3389/fcimb.2017.00236

Boulanger, N., Boyer, P., Talagrand-Reboul, E., Hansmann, Y., 2019. Ticks and tick-borne diseases. Med Mal Infect 49, 87-97. https://doi.org/10.1016/j.medmal.2019.01.007

Brucker, R.M., Bordenstein, S.R., 2012. Speciation by symbiosis. Trends Ecol. Evol. (Amst.) 27, 443-451. https://doi.org/10.1016/j.tree.2012.03.011 
Budachetri, K., Kumar, D., Crispell, G., Beck, C., Dasch, G., Karim, S., 2018. The tick endosymbiont Candidatus Midichloria mitochondrii and selenoproteins are essential for the growth of Rickettsia parkeri in the Gulf Coast tick vector. Microbiome 6, 141. https://doi.org/10.1186/s40168-018-0524-2

Cafiso, A., Bazzocchi, C., De Marco, L., Opara, M.N., Sassera, D., Plantard, O., 2016. Molecular screening for Midichloria in hard and soft ticks reveals variable prevalence levels and bacterial loads in different tick species. Ticks Tick Borne Dis 7, 11861192. https://doi.org/10.1016/j.ttbdis.2016.07.017

Cafiso, A., Sassera, D., Romeo, C., Serra, V., Hervet, C., Bandi, C., Plantard, O., Bazzocchi, C., 2019. Midichloria mitochondrii, endosymbiont of Ixodes ricinus: evidence for the transmission to the vertebrate host during the tick blood meal. Ticks Tick Borne Dis 10, 5-12. https://doi.org/10.1016/j.ttbdis.2018.08.008

Castelli, M., Sabaneyeva, E., Lanzoni, O., Lebedeva, N., Floriano, A.M., Gaiarsa, S., Benken, K., Modeo, L., Bandi, C., Potekhin, A., Sassera, D., Petroni, G., 2019. Deianiraea, an extracellular bacterium associated with the ciliate Paramecium, suggests an alternative scenario for the evolution of Rickettsiales. ISME J 13, 2280-2294. https://doi.org/10.1038/s41396-019-0433-9

Castelli, M., Sassera, D., Petroni, G., 2016. Biodiversity of “Non-model” Rickettsiales and Their Association with Aquatic Organisms, in: Thomas, S. (Ed.), Rickettsiales: Biology, Molecular Biology, Epidemiology, and Vaccine Development. Springer International Publishing, Cham, pp. 59-91. https://doi.org/10.1007/978-3-319-468594_3

Chrétien, D., Bénit, P., Ha, H.-H., Keipert, S., El-Khoury, R., Chang, Y.-T., Jastroch, M., Jacobs, H.T., Rustin, P., Rak, M., 2018. Mitochondria are physiologically maintained at close to $50^{\circ} \mathrm{C}$. PLoS Biol. 16, e2003992. https://doi.org/10.1371/journal.pbio.2003992

Cossart, P., 2011. Illuminating the landscape of host-pathogen interactions with the bacterium Listeria monocytogenes. Proc. Natl. Acad. Sci. U.S.A. 108, 19484-19491. https://doi.org/10.1073/pnas.1112371108

de Puytorac, P., Grain, J., 1972. [Intramitochondrial bacteria and pecularities of cytostomopharyngeal ultrastructure in the ciliate, Urotricha ovata Kahl (Ciliata)]. C. R. Seances Soc. Biol. Fil. 166, 604-607.

DeJong, R.J., Miller, L.M., Molina-Cruz, A., Gupta, L., Kumar, S., Barillas-Mury, C., 2007. Reactive oxygen species detoxification by catalase is a major determinant of fecundity in the mosquito Anopheles gambiae. Proc. Natl. Acad. Sci. U.S.A. 104, 2121-2126. https://doi.org/10.1073/pnas.0608407104

Di Lecce, I., Bazzocchi, C., Cecere, J.G., Epis, S., Sassera, D., Villani, B.M., Bazzi, G., Negri, A., Saino, N., Spina, F., Bandi, C., Rubolini, D., 2018. Patterns of Midichloria infection in avian-borne African ticks and their trans-Saharan migratory hosts. Parasit Vectors 11, 106. https://doi.org/10.1186/s13071-018-2669-z

Douglas, A.E., 2014. The molecular basis of bacterial-insect symbiosis. J. Mol. Biol. 426, 3830-3837. https://doi.org/10.1016/j.jmb.2014.04.005

Duron, O., Binetruy, F., Noël, V., Cremaschi, J., McCoy, K.D., Arnathau, C., Plantard, O., Goolsby, J., Pérez de León, A.A., Heylen, D.J.A., Van Oosten, A.R., Gottlieb, Y., 
Baneth, G., Guglielmone, A.A., Estrada-Peña, A., Opara, M.N., Zenner, L., Vavre, F., Chevillon, C., 2017. Evolutionary changes in symbiont community structure in ticks. Mol. Ecol. 26, 2905-2921. https://doi.org/10.1111/mec.14094

Duron, O., Morel, O., Noël, V., Buysse, M., Binetruy, F., Lancelot, R., Loire, E., Ménard, C., Bouchez, O., Vavre, F., Vial, L., 2018. Tick-Bacteria Mutualism Depends on B Vitamin Synthesis Pathways. Curr. Biol. 28, 1896-1902.e5. https://doi.org/10.1016/j.cub.2018.04.038

Dzeja, P., Terzic, A., 2009. Adenylate kinase and AMP signaling networks: metabolic monitoring, signal communication and body energy sensing. Int J Mol Sci 10, 1729 1772. https://doi.org/10.3390/ijms10041729

Epis, S., Sassera, D., Beninati, T., Lo, N., Beati, L., Piesman, J., Rinaldi, L., McCoy, K.D., Torina, A., Sacchi, L., Clementi, E., Genchi, M., Magnino, S., Bandi, C., 2008. Midichloria mitochondrii is widespread in hard ticks (Ixodidae) and resides in the mitochondria of phylogenetically diverse species. Parasitology 135, 485-494. https://doi.org/10.1017/S0031182007004052

Escoll, P., Song, O.R., Viana, F., Steiner, B., Lagache, T., Olivo-Marin, J.C., Impens, F., Brodin, P., Hilbi, H., Buchrieser, C., 2017. Legionella pneumophila Modulates Mitochondrial Dynamics to Trigger Metabolic Repurposing of Infected Macrophages. Cell Host Microbe 22, 302-316 e7. https://doi.org/10.1016/j.chom.2017.07.020

Ferla, M.P., Thrash, J.C., Giovannoni, S.J., Patrick, W.M., 2013. New rRNA gene-based phylogenies of the Alphaproteobacteria provide perspective on major groups, mitochondrial ancestry and phylogenetic instability. PLoS ONE 8, e83383. https://doi.org/10.1371/journal.pone.0083383

Fischer, K., Beatty, W.L., Weil, G.J., Fischer, P.U., 2014. High Pressure Freezing/Freeze Substitution Fixation Improves the Ultrastructural Assessment of Wolbachia Endosymbiont - Filarial Nematode Host Interaction. PLOS ONE 9, e86383. https://doi.org/10.1371/journal.pone.0086383

Fitzpatrick, D.A., Creevey, C.J., McInerney, J.O., 2006. Genome phylogenies indicate a meaningful alpha-proteobacterial phylogeny and support a grouping of the mitochondria with the Rickettsiales. Mol. Biol. Evol. 23, 74-85. https://doi.org/10.1093/molbev/msj009

Foo, J.H., Culvenor, J.G., Ferrero, R.L., Kwok, T., Lithgow, T., Gabriel, K., 2010. Both the p33 and p55 subunits of the Helicobacter pylori VacA toxin are targeted to mammalian mitochondria. J. Mol. Biol. 401, 792-798. https://doi.org/10.1016/j.jmb.2010.06.065

Gil, R., Latorre, A., 2019. Unity Makes Strength: A Review on Mutualistic Symbiosis in Representative Insect Clades. Life (Basel) 9. https://doi.org/10.3390/life9010021

Gray, M.W., Burger, G., Lang, B.F., 2001. The origin and early evolution of mitochondria. Genome Biol. 2, REVIEWS1018. https://doi.org/10.1186/gb-2001-2-6-reviews1018

Green, D.R., Galluzzi, L., Kroemer, G., 2014. Cell biology. Metabolic control of cell death. Science 345, 1250256. https://doi.org/10.1126/science.1250256

Haiko, J., Westerlund-Wikström, B., 2013. The role of the bacterial flagellum in adhesion and virulence. Biology (Basel) 2, 1242-1267. https://doi.org/10.3390/biology2041242 
Hernández-Jarguín, A., Díaz-Sánchez, S., Villar, M., de la Fuente, J., 2018. Integrated metatranscriptomics and metaproteomics for the characterization of bacterial microbiota in unfed Ixodes ricinus. Ticks Tick Borne Dis 9, 1241-1251. https://doi.org/10.1016/j.ttbdis.2018.04.020

Horwitz, M.A., 1983. Formation of a novel phagosome by the Legionnaires' disease bacterium (Legionella pneumophila) in human monocytes. J. Exp. Med. 158, 13191331. https://doi.org/10.1084/jem.158.4.1319

Hosokawa, T., Koga, R., Kikuchi, Y., Meng, X.-Y., Fukatsu, T., 2010. Wolbachia as a bacteriocyte-associated nutritional mutualist. Proc. Natl. Acad. Sci. U.S.A. 107, 769774. https://doi.org/10.1073/pnas.0911476107

Kernif, T., Leulmi, H., Raoult, D., Parola, P., 2016. Emerging Tick-Borne Bacterial Pathogens. Microbiol Spectr 4. https://doi.org/10.1128/microbiolspec.EI10-0012-2016

Landmann, F., 2019. The Wolbachia Endosymbionts. Microbiol Spectr 7. https://doi.org/10.1128/microbiolspec.BAI-0018-2019

Lejal, E., Moutailler, S., Šimo, L., Vayssier-Taussat, M., Pollet, T., 2019. Tick-borne pathogen detection in midgut and salivary glands of adult Ixodes ricinus. Parasit Vectors 12, 152. https://doi.org/10.1186/s13071-019-3418-7

Leulier, F., Lemaitre, B., 2008. Toll-like receptors--taking an evolutionary approach. Nat. Rev. Genet. 9, 165-178. https://doi.org/10.1038/nrg2303

Lo, N., Beninati, T., Sassera, D., Bouman, E. a. P., Santagati, S., Gern, L., Sambri, V., Masuzawa, T., Gray, J.S., Jaenson, T.G.T., Bouattour, A., Kenny, M.J., Guner, E.S., Kharitonenkov, I.G., Bitam, I., Bandi, C., 2006. Widespread distribution and high prevalence of an alpha-proteobacterial symbiont in the tick Ixodes ricinus. Environ. Microbiol. 8, 1280-1287. https://doi.org/10.1111/j.1462-2920.2006.01024.x

Mariconti, M., Epis, S., Gaibani, P., Dalla Valle, C., Sassera, D., Tomao, P., Fabbi, M., Castelli, F., Marone, P., Sambri, V., Bazzocchi, C., Bandi, C., 2012a. Humans parasitized by the hard tick Ixodes ricinus are seropositive to Midichloria mitochondrii: is Midichloria a novel pathogen, or just a marker of tick bite? Pathog Glob Health 106, 391-396. https://doi.org/10.1179/2047773212Y.0000000050

Mariconti, M., Epis, S., Sacchi, L., Biggiogera, M., Sassera, D., Genchi, M., Alberti, E., Montagna, M., Bandi, C., Bazzocchi, C., 2012b. A study on the presence of flagella in the order Rickettsiales: the case of "Candidatus Midichloria mitochondrii."

Microbiology (Reading, Engl.) 158, 1677-1683. https://doi.org/10.1099/mic.0.057174-0

Martijn, J., Vosseberg, J., Guy, L., Offre, P., Ettema, T.J.G., 2018. Deep mitochondrial origin outside the sampled alphaproteobacteria. Nature 557, 101-105. https://doi.org/10.1038/s41586-018-0059-5

Matsumoto, A., Bessho, H., Uehira, K., Suda, T., 1991. Morphological studies of the association of mitochondria with chlamydial inclusions and the fusion of chlamydial inclusions. J Electron Microsc (Tokyo) 40, 356-363.

Monnot, S., Samuels, D.C., Hesters, L., Frydman, N., Gigarel, N., Burlet, P., Kerbrat, V., Lamazou, F., Frydman, R., Benachi, A., Feingold, J., Rotig, A., Munnich, A., Bonnefont, J.-P., Steffann, J., 2013. Mutation dependance of the mitochondrial DNA 
copy number in the first stages of human embryogenesis. Hum. Mol. Genet. 22, 18671872. https://doi.org/10.1093/hmg/ddt040

Moran, N.A., McCutcheon, J.P., Nakabachi, A., 2008. Genomics and evolution of heritable bacterial symbionts. Annu. Rev. Genet. 42, 165-190. https://doi.org/10.1146/annurev.genet.41.110306.130119

Moutailler, S., Valiente Moro, C., Vaumourin, E., Michelet, L., Tran, F.H., Devillers, E., Cosson, J.-F., Gasqui, P., Van, V.T., Mavingui, P., Vourc'h, G., Vayssier-Taussat, M., 2016. Co-infection of Ticks: The Rule Rather Than the Exception. PLoS Negl Trop Dis 10, e0004539. https://doi.org/10.1371/journal.pntd.0004539

Mueller, K.E., Plano, G.V., Fields, K.A., 2014. New frontiers in type III secretion biology: the Chlamydia perspective. Infect. Immun. 82, 2-9. https://doi.org/10.1128/IAI.00917-13

Nakahira, K., Haspel, J.A., Rathinam, V.A.K., Lee, S.-J., Dolinay, T., Lam, H.C., Englert, J.A., Rabinovitch, M., Cernadas, M., Kim, H.P., Fitzgerald, K.A., Ryter, S.W., Choi, A.M.K., 2011. Autophagy proteins regulate innate immune responses by inhibiting the release of mitochondrial DNA mediated by the NALP3 inflammasome. Nat. Immunol. 12, 222-230. https://doi.org/10.1038/ni.1980

Nunnari, J., Suomalainen, A., 2012. Mitochondria: in sickness and in health. Cell 148, 11451159. https://doi.org/10.1016/j.cell.2012.02.035

Olivieri, E., Epis, S., Castelli, M., Varotto Boccazzi, I., Romeo, C., Desirò, A., Bazzocchi, C., Bandi, C., Sassera, D., 2019. Tissue tropism and metabolic pathways of Midichloria mitochondrii suggest tissue-specific functions in the symbiosis with Ixodes ricinus. Ticks Tick Borne Dis 10, 1070-1077. https://doi.org/10.1016/j.ttbdis.2019.05.019

Orrenius, S., Gogvadze, V., Zhivotovsky, B., 2015. Calcium and mitochondria in the regulation of cell death. Biochem. Biophys. Res. Commun. 460, 72-81. https://doi.org/10.1016/j.bbrc.2015.01.137

Parkes, T.L., Kirby, K., Phillips, J.P., Hilliker, A.J., 1998. Transgenic analysis of the cSODnull phenotypic syndrome in Drosophila. Genome 41, 642-651.

Parola, P., Paddock, C.D., Socolovschi, C., Labruna, M.B., Mediannikov, O., Kernif, T., Abdad, M.Y., Stenos, J., Bitam, I., Fournier, P.-E., Raoult, D., 2013. Update on tickborne rickettsioses around the world: a geographic approach. Clin. Microbiol. Rev. 26, 657-702. https://doi.org/10.1128/CMR.00032-13

Pernas, L., Scorrano, L., 2016. Mito-Morphosis: Mitochondrial Fusion, Fission, and Cristae Remodeling as Key Mediators of Cellular Function. Annu. Rev. Physiol. 78, 505-531. https://doi.org/10.1146/annurev-physiol-021115-105011

Perner, J., Sobotka, R., Sima, R., Konvickova, J., Sojka, D., Oliveira, P.L. de, Hajdusek, O., Kopacek, P., 2016. Acquisition of exogenous haem is essential for tick reproduction. Elife 5. https://doi.org/10.7554/eLife.12318

Polčic, P., Mentel, M., Gavurníková, G., Bhatia-Kiššová, I., 2017. To keep the host alive - the role of viral Bcl-2 proteins. Acta Virol. 61, 240-251. https://doi.org/10.4149/av_2017_302

Reis, C., Cote, M., Paul, R.E.L., Bonnet, S., 2011. Questing ticks in suburban forest are infected by at least six tick-borne pathogens. Vector Borne Zoonotic Dis. 11, 907916. https://doi.org/10.1089/vbz.2010.0103 
Roger, A.J., Muñoz-Gómez, S.A., Kamikawa, R., 2017. The Origin and Diversification of Mitochondria. Curr. Biol. 27, R1177-R1192. https://doi.org/10.1016/j.cub.2017.09.015

Rudel, T., Kepp, O., Kozjak-Pavlovic, V., 2010. Interactions between bacterial pathogens and mitochondrial cell death pathways. Nat Rev Microbiol 8, 693-705. https://doi.org/10.1038/nrmicro2421

Sacchi, L., Bigliardi, E., Corona, S., Beninati, T., Lo, N., Franceschi, A., 2004. A symbiont of the tick Ixodes ricinus invades and consumes mitochondria in a mode similar to that of the parasitic bacterium Bdellovibrio bacteriovorus. Tissue Cell 36, 43-53. https://doi.org/10.1016/j.tice.2003.08.004

Sassera, D., Beninati, T., Bandi, C., Bouman, E.A.P., Sacchi, L., Fabbi, M., Lo, N., 2006. "Candidatus Midichloria mitochondrii", an endosymbiont of the tick Ixodes ricinus with a unique intramitochondrial lifestyle. Int. J. Syst. Evol. Microbiol. 56, 25352540. https://doi.org/10.1099/ijs.0.64386-0

Sassera, D., Lo, N., Bouman, E.A.P., Epis, S., Mortarino, M., Bandi, C., 2008. “Candidatus Midichloria" endosymbionts bloom after the blood meal of the host, the hard tick Ixodes ricinus. Appl. Environ. Microbiol. 74, 6138-6140. https://doi.org/10.1128/AEM.00248-08

Sassera, D., Lo, N., Epis, S., D’Auria, G., Montagna, M., Comandatore, F., Horner, D., Peretó, J., Luciano, A.M., Franciosi, F., Ferri, E., Crotti, E., Bazzocchi, C., Daffonchio, D., Sacchi, L., Moya, A., Latorre, A., Bandi, C., 2011. Phylogenomic evidence for the presence of a flagellum and $\operatorname{cbb}(3)$ oxidase in the free-living mitochondrial ancestor. Mol. Biol. Evol. 28, 3285-3296. https://doi.org/10.1093/molbev/msr159

Schmitz-Esser, S., Haferkamp, I., Knab, S., Penz, T., Ast, M., Kohl, C., Wagner, M., Horn, M., 2008. Lawsonia intracellularis contains a gene encoding a functional rickettsialike ATP/ADP translocase for host exploitation. J. Bacteriol. 190, 5746-5752. https://doi.org/10.1128/JB.00391-08

Serra, V., Krey, V., Daschkin, C., Cafiso, A., Sassera, D., Maxeiner, H.-G., Modeo, L., Nicolaus, C., Bandi, C., Bazzocchi, C., 2019. Seropositivity to Midichloria mitochondrii (order Rickettsiales) as a marker to determine the exposure of humans to tick bite. Pathog Glob Health 113, 167-172. https://doi.org/10.1080/20477724.2019.1651568

Shimoyama, T., Kato, S., Ishii, S., Watanabe, K., 2009. Flagellum mediates symbiosis. Science 323, 1574. https://doi.org/10.1126/science.1170086

Spier, A., Stavru, F., Cossart, P., 2019. Interaction between Intracellular Bacterial Pathogens and Host Cell Mitochondria. Microbiol Spectr 7. https://doi.org/10.1128/microbiolspec.BAI-0016-2019

Stavru, F., Bouillaud, F., Sartori, A., Ricquier, D., Cossart, P., 2011. Listeria monocytogenes transiently alters mitochondrial dynamics during infection. Proceedings of the National Academy of Sciences of the United States of America 108, 3612-3617. https://doi.org/10.1073/pnas.1100126108 
Tashyreva, D., Prokopchuk, G., Votýpka, J., Yabuki, A., Horák, A., Lukeš, J., 2018. Life Cycle, Ultrastructure, and Phylogeny of New Diplonemids and Their Endosymbiotic Bacteria. MBio 9. https://doi.org/10.1128/mBio.02447-17

Taylor, M.J., Bandi, C., Hoerauf, A., 2005. Wolbachia bacterial endosymbionts of filarial nematodes. Adv. Parasitol. 60, 245-284. https://doi.org/10.1016/S0065308X(05)60004-8

Tilney, L.G., Portnoy, D.A., 1989. Actin filaments and the growth, movement, and spread of the intracellular bacterial parasite, Listeria monocytogenes. J Cell Biol 109, 15971608. https://doi.org/10.1083/jcb.109.4.1597

Tiwari, M., Prasad, S., Tripathi, A., Pandey, A.N., Ali, I., Singh, A.K., Shrivastav, T.G., Chaube, S.K., 2015. Apoptosis in mammalian oocytes: a review. Apoptosis 20, 10191025. https://doi.org/10.1007/s10495-015-1136-y

Toft, C., Fares, M.A., 2008. The evolution of the flagellar assembly pathway in endosymbiotic bacterial genomes. Mol. Biol. Evol. 25, 2069-2076. https://doi.org/10.1093/molbev/msn153

Trentmann, O., Horn, M., van Scheltinga, A.C.T., Neuhaus, H.E., Haferkamp, I., 2007. Enlightening energy parasitism by analysis of an ATP/ADP transporter from chlamydiae. PLoS Biol. 5, e231. https://doi.org/10.1371/journal.pbio.0050231

Wang, H.-C., Xia, X., Hickey, D., 2006. Thermal Adaptation of the Small Subunit Ribosomal RNA Gene: A Comparative Study. J Mol Evol 63, 120-126. https://doi.org/10.1007/s00239-005-0255-4

Wang, Z., Wu, M., 2015. An integrated phylogenomic approach toward pinpointing the origin of mitochondria. Sci Rep 5, 1-12. https://doi.org/10.1038/srep07949

Waterman, S.R., Holden, D.W., 2003. Functions and effectors of the Salmonella pathogenicity island 2 type III secretion system. Cell. Microbiol. 5, 501-511. https://doi.org/10.1046/j.1462-5822.2003.00294.x

Weinert, L.A., Werren, J.H., Aebi, A., Stone, G.N., Jiggins, F.M., 2009. Evolution and diversity of Rickettsia bacteria. BMC Biol. 7, 6. https://doi.org/10.1186/1741-7007-76

Wernegreen, J.J., 2012. Endosymbiosis. Curr. Biol. 22, R555-561. https://doi.org/10.1016/j.cub.2012.06.010

Werren, J.H., Baldo, L., Clark, M.E., 2008. Wolbachia: master manipulators of invertebrate biology. Nat. Rev. Microbiol. 6, 741-751. https://doi.org/10.1038/nrmicro1969

Westermann, B., 2010. Mitochondrial dynamics in model organisms: what yeasts, worms and flies have taught us about fusion and fission of mitochondria. Semin. Cell Dev. Biol. 21, 542-549. https://doi.org/10.1016/j.semcdb.2009.12.003

Williams, K.P., Sobral, B.W., Dickerman, A.W., 2007. A robust species tree for the alphaproteobacteria. J. Bacteriol. 189, 4578-4586. https://doi.org/10.1128/JB.0026907

Winkler, H.H., Daugherty, R.M., 1984. Regulatory role of phosphate and other anions in transport of ADP and ATP by Rickettsia prowazekii. J. Bacteriol. 160, 76-79.

Yamataka, S., Hayashi, R., 1970. Electron microscopic studies on the mitochondria and intramitochondrial microorganisms of Halteria geleiana. J Electron Microsc (Tokyo) 19, 50-62. 
Zhang, L., Krachler, A.M., Broberg, C.A., Li, Y., Mirzaei, H., Gilpin, C.J., Orth, K., 2012. Type III effector VopC mediates invasion for Vibrio species. Cell Rep 1, 453-460. https://doi.org/10.1016/j.celrep.2012.04.004

Zug, R., Hammerstein, P., 2015. Wolbachia and the insect immune system: what reactive oxygen species can tell us about the mechanisms of Wolbachia-host interactions. Front Microbiol 6, 1201. https://doi.org/10.3389/fmicb.2015.01201

This article is protected by copyright. All rights reserved. 

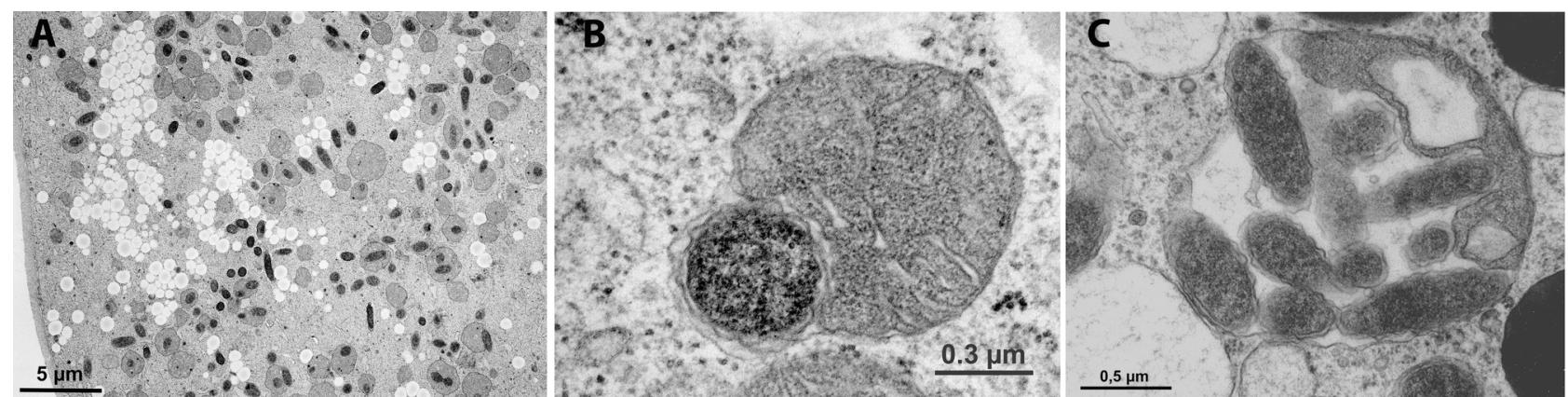

CMI_13189_Fig1.tif

This article is protected by copyright. All rights reserved. 


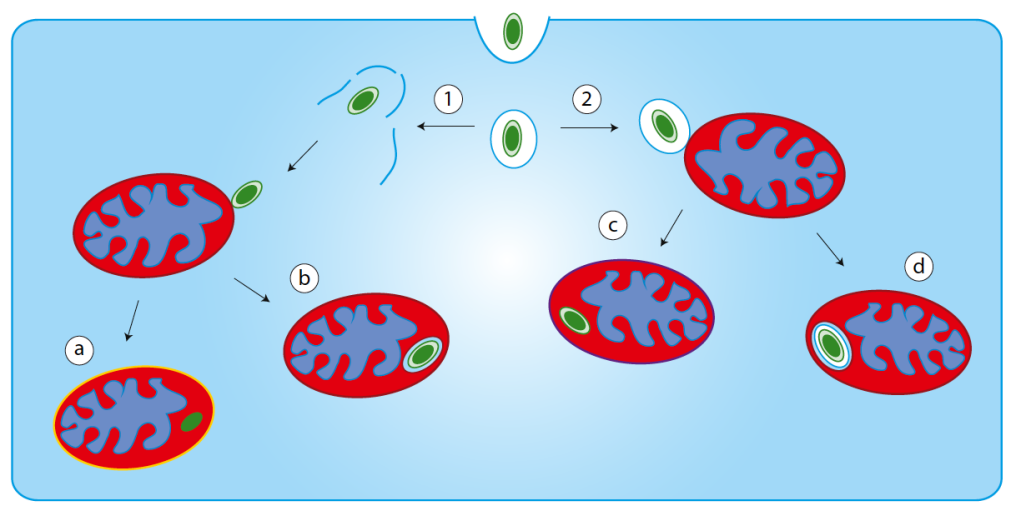

CMI_13189_Fig2_Midi_lifecycle.tif

This article is protected by copyright. All rights reserved. 


\section{University Library}

\section{- M M N E R VA A gateway to Melbourne's research publications}

Minerva Access is the Institutional Repository of The University of Melbourne

Author/s:

Stavru, F;Riemer, J;Jex, A;Sassera, D

Title:

When bacteria meet mitochondria: The strange case of the tick symbiont Midichloria mitochondrii(dagger)

Date:

2020-04-01

Citation:

Stavru, F., Riemer, J., Jex, A. \& Sassera, D. (2020). When bacteria meet mitochondria: The strange case of the tick symbiont Midichloria mitochondrii(dagger). CELLULAR MICROBIOLOGY, 22 (4), https://doi.org/10.1111/cmi.13189.

Persistent Link:

http://hdl.handle.net/11343/275581 